\title{
Acute Myocardial Infarction Due to Elevated Levels of Factor VIII
}

\section{Schamroth Colin*}

Specialist Cardiologist, South Africa

\begin{abstract}
A 22 year old highly trained sportsman presented to the emergency room with chest pain associated with sweating and pain down the left arm. He had presented to the same ER the previous day with non-specific symptoms and nausea, but felt better after bringing up bile stained fluid. The ECG taken the previous day was reported as being normal and he was sent home after an hs-Troponin $T$ of $<5 \mathrm{ng} / \mathrm{ml}$ was obtained. The ECG on the second occasion showed an evolved inferior wall infarction with posterior wall extension. Repeat cardiac enzymes now showed an elevated hs-Troponin T of $4345 \mathrm{ng} / \mathrm{ml}$ and a CK of $1227 \mathrm{U} / \mathrm{L}$. He was taken to the CCU and treated as an acute coronary syndrome. Subsequent coronary angiography showed smooth-walled coronary arteries with the left coronary system being totally patent. The right coronary artery showed filling defects suggestive of residual thrombus in the lumen.
\end{abstract}

Keywords: Factor VIII; Coronary thrombosis; Myocardial infarction

\section{Introduction}

A 22 year old highly trained sportsman presented to the emergency room with chest pain associated with sweating and pain down the left arm. He had presented to the same ER the previous day with nonspecific symptoms and nausea, but felt better after bringing up bile stained fluid. The ECG taken the previous day was reported as being normal and he was sent home after an hs-Troponin $\mathrm{T}$ of $<5 \mathrm{ng} / \mathrm{ml}$ was obtained. The ECG on the second occasion showed an evolved inferior wall infarction with posterior wall extension. Repeat cardiac enzymes now showed an elevated hs-Troponin $\mathrm{T}$ of $4345 \mathrm{ng} / \mathrm{ml}$ and a CK of $1227 \mathrm{U} / \mathrm{L}$. He was taken to the CCU and treated as an acute coronary syndrome. Subsequent coronary angiography showed smooth-walled coronary arteries with the left coronary system being totally patent. The right coronary artery showed filling defects suggestive of residual thrombus in the lumen (Figure 1).

The patient's father had had a stent implanted into one of his coronary arteries at the age of 52 years, and on his mother's side there were family members who had had deep vein thromboses and documented Protein S deficiency. The patient's total cholesterol was $4.7 \mathrm{mmol} / \mathrm{L}$ with a LDL-C of $3.3 \mathrm{mmol} / \mathrm{L}$. A full thrombotic screen was then requested. He was found to have an elevated homocystein level of $31 \mathrm{umol} / \mathrm{L}$ and supernormal levels of Factor VIII of $451 \mathrm{IU} / \mathrm{dL}$ (ref range 50-150 IU/dL). He did not have Protein S deficiency or any other of the inherited thrombophilias.

Several studies have suggested that elevated levels of Factor VIII are a risk factor for atherosclerotic coronary artery disease [1,2]. Levels reported as indicating risk is generally only mildly or moderately above the reference range. Elevated levels of Factor VIII are associated with an increased risk of thromboembolism, but this is mostly for venous thromboembolism [3,4].Whilst there is an added risk for arterial thrombosis, this is usually in the presence of established atherosclerotic disease. There are few reports of spontaneous arterial (and more specifically coronary) thrombosis $[5,6]$. There has been a single report of acute coronary arterial occlusion occurring during infusion of recombinant Factor VIII in a patient with haemophilia [7]. Whether the infusion raised the Factor VIII levels to the super-normal levels observed in this case is uncertain, but the thrombosis may have been related to a sudden change in Factor VIII levels.

\section{Conclusion}

The current case did not have any atherosclerotic disease and the myocardial infarction was almost certainly due to spontaneous thrombosis within a normal vessel, as a direct consequence of the markedly elevated levels of Factor VIII. This is certainly unusual, but such an abnormality should be considered when myocardial infarction occurs in a young patient in the absence of the usual risk factors for coronary artery disease.

\section{References}

1. Kamphuisen JW, Eikenboom JCJ, Bertina RM (2001) Elevated Factor VIII levels and the risk of thrombosis. Arterioscler Thromb Vasc Biol 21: 731-738.

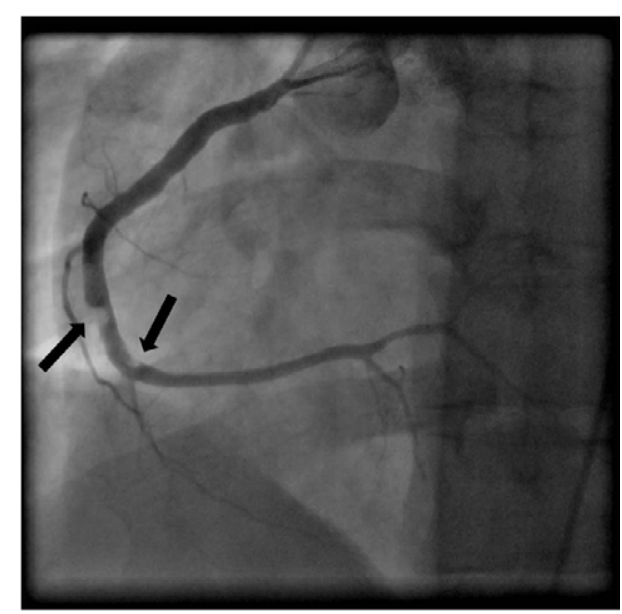

Figure 1: Coronary angiogram showing the right coronary artery. Arrows show intraluminal filling defects indicative of thrombus.

*Corresponding author: Schamroth Colin, Specialist Cardiologist, Greenside South Africa, Tel: 726-6391; Fax: 482-1445; E-mail: cscham@global.co.za

Received August 21, 2013; Accepted September 16, 2013; Published September 23, 2013

Citation: Colin S (2013) Acute Myocardial Infarction Due to Elevated Levels of Factor VIII. J Cardiovasc Dis Diagn 1: 126. doi:10.4172/2329-9517.1000126

Copyright: @ 2013 Colin S. This is an open-access article distributed under the terms of the Creative Commons Attribution License, which permits unrestricted use, distribution, and reproduction in any medium, provided the original author and source are credited. 
Citation: Colin S (2013) Acute Myocardial Infarction Due to Elevated Levels of Factor VIII. J Cardiovasc Dis Diagn 1: 126. doi:10.4172/23299517.1000126

Page 2 of 2

2. Rumley A, Lowe GD, Sweetnam PM, Yarnell JW, Ford RP (1999) Factor VIII, von Willebrand factor and the risk of major ischaemic heart disease in the Caerphilly Heart Study. Br J Haematol 105: 110-116.

3. Kyrle PA, Minar E, Hirschl M, Bialoncyk C, Stain M, et al. (2000) High plasma levels of factor VIII and the risk of recurrent venous thromboembolism. N Engl J Med 343: 457-462.

4. Jenkins PV, Rawley O, Smith OP, O'Donnell JS (2012) Elevated factor VIII levels and risk of venous thrombosis. $\mathrm{Br} \mathrm{J}$ Haematol 157: 653-663.

5. Gorog DA, Rakhit R, Parums D, Laffan M, Davies GJ (1998) Raised factor VIII is associated with coronary thrombotic events. Heart 80: 415-417.
6. Hernandez V, Munoz N, Montero MA, Cmacho A, Lozano F, et al. (2012) Acute myocardial infarction for thrombotic occlusion in patient with elevated coagulation factor VIII. Rev Esp Cardiol (Engl Ed) 65: 673-674.

7. Alsolaiman MM, Chang C, Arjomand H, Ozra R, Costacurta G (2000) Acute left anterior descending artery occlusion in a haemophiliac $A$ patient during recombinant factor VIII infusion: Treatment with coronary angioplasty. Catheter Cardiovasc Interv 50: 468-472. 